Asian Pacific Journal of Reproduction

Journal homepage: www.apjr.net

\title{
Plants altering hormonal milieu: A review
}

\author{
Prashant Tiwari ${ }^{\circledR}$, Pratap Kumar Sahu \\ Department of Pharmacology, School of Pharmaceutical Sciences, Siksha 'O' Anusandhan University, Bhubaneswar
}

\section{ARTICLE INFO}

Article history:

Received 2 January 2017

Revision 10 February 2017

Accepted 15 February 2017

Available online 1 March 2017

\section{Keywords:}

Hormone

Medicinal plant

\begin{abstract}
The aim of the present review article is to investigate the herbs which can alter the levels of hormones like Follicle stimulating hormone, Prolactin, Growth hormone, Insulin, Thyroxine, Estrogen, Progesterone, Testosterone, and Relaxin etc. Hormones are chemical signal agents produced by different endocrine glands for regulating our biological functions. The glands like pituitary, thyroid, adrenal, ovaries in women and testes in men all secrete a number of hormones with different actions. However, when these hormones are perfectly balanced then people become healthy and fit. But several factors like pathophysiological as well as biochemical changes, disease conditions, changes in the atmosphere, changes in the body, diet changes etc. may result in imbalance of various hormones that produce undesirable symptoms and disorders. As medicinal plants have their importance since ancient time, people have been using it in various ways as a source of medicine for regulation of hormonal imbalance. Moreover, it is observed that certain herbs have a balancing effect on hormones and have great impact on well-being of the people. So, considering these facts we expect that the article provides an overview on medicinal plants with potential of altering hormone level.
\end{abstract}

\section{Introduction}

There are two important systems in human beings, which control and maintain the homeostasis i.e. maintaining the internal environment in a balanced state. First and foremost important system is nervous system with the help of functioning cells called neurons. These neurons are characterized by their conductivity with the help of neurotransmitters i.e. chemical mediators. This nervous system is well organized and function efficiently in human beings. Second important system is also organized and efficiently function with other set of chemical messengers known as hormones.

Hormones are chemical messengers synthesised by the ductless glands and released in the blood and they execute their functions

\footnotetext{
Corresponding author: Prashant Tiwari, Department of Pharmacology, School of Pharmaceutical Sciences, Siksha 'O' Anusandhan University, Bhubaneswar.

E-mail : prashanttiwari@soauniversity.ac.in

Foundation project: This work was financially supported in form of fellowship by the Indian Council of Medical Research (ICMR), New Delhi, India (45/5/2013/BMS/TRM).
}

at their target organs which are far away from the site of release. Hormones are chemically of two types: peptides and steroidal in nature. The major endocrine glands include the pineal gland, pituitary gland, pancreas, ovaries, testes, thyroid gland, parathyroid gland, and adrenal glands. A wide variety of these chemical substances are produced by endocrine cells, most of which are in glands. The peptide hormones are synthesized from the gene expression by the specific genes to express the final proteins and also the specific enzymes for the conversion of cholesterol into steroids in case of steroidal hormones. If these expression alter, there may be the chances of hormonal imbalance. In most of the

This is an open access article distributed under the terms of the Creative Commons Attribution-Non Commercial-Share Alike 3.0 License, which allows others to remix, tweak and buid upon the work non-commercially, as long as the author is credited and the new creations are licensed under the identical terms.

For reprints contact: reprints@medknow.com

C2017 Asian Pacific Journal of Reproduction Produced by Wolters Kluwer- Medknow

How to cite this article: Prashant Tiwari, Pratap Kumar Sahu. Plants altering hormonal milieu: A review. Asian Pac J Reprod 2017; 6(2): 49-53. 
case secretion of various hormones are defective which can be corrected by administration of hormones. If excessive production of hormones are there, that also leads to hyper functions which can be corrected by the corresponding antagonists.

In this review, the authors have covered various medicinal plants and their importance in altering the level of hormones. Hormones exhibit their action by medicating G-protein coupled, Tyrosine kinase and nucleic acid receptors. There are many hormones produced by the endocrine glands. Their primary functions are as follow.

\subsection{Pituitary hormones}

Most of the peptides are synthesized and released by master gland known as pituitary gland. This gland gets stimulus from hypothalamus whenever body requires such hormones by negative feedback mechanism. The anterior pituitary hormones are growth hormone $(\mathrm{GH})$, Thyroid stimulating hormone (TSH), Adrenocorticotropic hormone (ACTH), Follicle stimulating hormone (FSH) etc. The posterior pituitary hormones are oxytocin and vasopressin.

\subsection{Steroid gland hormones}

Steroidal hormones are synthesized in adrenal and gonads in both male and females. These steroids are synthesized by using cholesterol as a precursor with the help of enzymes. The major function of peptide hormones are to influence the metabolism and growth, but the steroidal hormones are influencing the fluid balance and development of secondary sexual characters of both male and females.

\subsection{Pancreas hormones}

The pancreas secretes hormones (insulin and glucagon) and digestive enzymes. The pancreas maintains the body blood glucose balance. However the diabetes is the most common disorder associated with the pancreas.

\subsection{Adrenal gland hormones}

The adrenal gland located at the anterior part of the kidneys, and covered with the connective tissue. The adrenal glands have very different function such as regulate metabolism, maintain blood pressure, and regulate sodium and potassium balance in the body. The adrenal hormones from adrenal cortex are Mineralocorticoids,
Glucocorticoids and sex hormones. The hormones from adrenal medulla is adrenaline.

\subsection{Reproductive organs hormones}

Testes secrete testosterone, which is responsible for the physical development and function of the male reproductive system. The ovaries in females secrete estrogen and progesterone. Estrogens are steroids. They are primarily responsible for broadening of the pelvis, development of breasts and further development of the uterus and vagina. Progesterone is also a steroid. Progesterone has important role in the menstrual cycle and pregnancy. The placenta becomes a major source of progesterone and it maintains pregnancy. However placenta release a large amount of corticotropin releasing hormone which stimulate pituitary glands[1].

\section{Plant derived hormones}

The hormones, which are made from plants, are known as phytohormones. There are number of plants that have estrogen and progesterone like substances. Plant derived hormones may enhance the action of present hormones by increasing concentration of one hormone, thereby diminishing the effect of another and mimic the action of various hormones and showing anabolic effect and androgenic effects. It was also noticed that the plant supplements containing plant derived hormones are safe[2].

\section{Herbs for balancing hormones}

The hormones play an important role in the body cell and affect our health in various dimension of the world's population. Nowadays trust on medicinal plant and depend on plant based diet for their existence can balance our hormones in various ways by using herbs. The most important thing is that the herbs have a less chance of adverse effect. Therefore, it can have a great impact on regulation of hormones. We have tried to look upon such herbs that could be more helpful for altering hormonal milieu.

\subsection{Astragalus}

The hormone balancing property of Astragalus helps in regulating blood pressure and blood sugar levels. In Mastalgia, women release more prolactin, and studies have shown that chasteberry extracts 
reduce prolactin levels in blood[3].

\subsection{Ashwagandha (withenia somnifera)}

Ashwagandha reduce the stress hormones which disturb endocrine function and rapid premature aging[4].

\subsection{Maca root (lipidium meyenii)}

Maca root has plant hormones that discuss benefits to women such as relieving premenstrual syndrome and menopausal symptoms. It has been found that healthy men receiving Lepidium meyenii for a period of 4 mo and showed significant increase in seminal volume, sperm count, and sperm motility. However, Serum hormone levels such as LH, FSH, prolactin, estradiol, and testosterone were not affected in women[5,6].

\subsection{Saw palmetto (seranoa repens)}

The whole part of Serenoa repens has a balancing effect on the endocrine system and on both male and female reproductive system.

It is examined that hyperprolactinemia increases weight and induces hyperplasia in the lateral prostate (LP). Lipidosterolic extract of Serenoa significantly reduced LP growth and hyperplasia in sulpiride treated rats. In addition, lipidosterolic extract of Serenoa repens inhibited the androgenic as well as trophic effect of prolactin (PRL) in rat[7].

\subsection{Chasteberry (vitex agnus-castus)}

Vitex agnus castus extract acts on the pituitary gland and regulate hormones like estrogen, follicle stimulating hormone (FSH), luteinizing hormone, and prolactin[8]. The flavonoid constituents of Vitex has selective binding affinity for $\beta$ estrogen receptor. Additionally, in vitro studies deliver extensive evidence of prolactin inhibition with the direct binding to $\mathrm{D}_{2}$ receptor. However, Vitex extract does not modulate follicle stimulating hormone (FSH) or luteinizing hormone (LH) production in rat pituitary gland[9-11].

It is also reported that inhibition of FSH and stimulation of LH secretion affected the progesterone and estrogen hormone level. It is a significant decrease secretion by $\mathrm{D}_{2}$ receptor antagonism. It is also noticed that Vitex extract has great impact on prolactin secretion and study also demonstrated high-dose Vitex inhibits secretion of prolactin in male rats and decreases milk production in lactating rats. Moreover, menstrual cycle irregularities due to hyperprolactinemia, corpus luteum insufficiency, and oligomenorrhea have been treated with Vitex extract. Furthermore, current experimental studies indicate that Vitex is widely used for the management of hyperprolactinemia. Vitex extract is able to moderate progesterone and menstrual cycle irregularities[12-18].

\subsection{Black cohosh (actaea racemosa)}

The ethanolic extracts of $C$. racemosa has estrogenic activity on primary pituitary cells. The ethanolic extract significantly reduced prolactin secretion of primary pituitary cell. For instance prolactin secretion by $C$. racemosa was reduced by the $\mathrm{D}_{2}$ receptor antagonist haloperidol which showed the dopaminergic activity of $C$. racemosa[19].

The effect of $C$. racemosa on bone loss may be connected with its capacity to reduce prolactin levels through $\mathrm{D}_{2}$-receptor antagonism. However, high prolactin levels have been associated mainly due to associated hypogonadism[20].

\subsection{Cissampelos pareira}

The leaf extract of Cissampelos pareira showed altered LH, FSH, prolactin and estradiol secretion[21].

\subsection{Jatropha gossypifolia}

Jatropha gossypifolia extract altered the $\mathrm{LH}, \mathrm{FSH}$, prolactin and estradiol secretion[22].

\subsection{Mimosa pudica}

Methanolic extract of Mimosa pudica significantly increase in the duration of the diestrous. The extract also changed gonadotropin release and estradiol secretion[23].

\subsection{Butea monosperma}

Alcoholic extract of Butea monosperma has reported to possess antiestrogenic effect[24,25]. The alcoholic extract of Butea monosperma has anti-ovulatory and anti-implantation activities. However, the active constituent of Butea monosperma is butin which exhibited estrogenic activity[26-29]. Butin also exhibits male contraceptive properties. Butea monosperma seed extract has antifertility effect. Methanolic extracts of Butea monosperma 
exhibited uterotropic and uterine peroxidase activities and antifertility effect[30-31].

\subsection{Nigella sativa}

The oral administration of Nigella sativa seeds extract at $2 \mathrm{~g} / \mathrm{kg}$ daily showed significant anti-fertility activity[32,33]. Nigella sativa oil ( $1 \mathrm{~mL} / \mathrm{kg}$ BW/day) administered orally for $30 \mathrm{~d}$ significantly increase Luteinizing hormone ( $\mathrm{LH}$ ) and this effect may be due to the effect of oil on hypothalamus[34,35]. The aqueous extract $(0.5 \mathrm{~g} /$ $\mathrm{kg}$ ) and ethanolic extracts of Nigella sativa $(1 \mathrm{~g} / \mathrm{kg})$ increased milk production significantly.

\subsection{Acacia nilotica}

Acacia nilotica extract showed that it stimulates synthesis and release of prolactin (PRL) significantly. Moreover, the aqueous extract of Acacia nilotica may stimulate milk production and PRL release[36].

\subsection{Black cohosh}

Black cohosh contains triterpene glycosides which contributes to improvement of estrogenic symptoms.

Black cohosh has also decreased hot flashes, increased blood flow, and improved hormone related depression[37].

\subsection{Don quai}

Don quai influences the estrogen receptor to improve estrogen activity[38,39]. It also increases vaginal lubrication. Chaste tea has been used to treat premenstrual syndrome, menstrual irregularities, and hyperprolactinemia[40]. The herb has an affinity for $\mathrm{D}_{1}$ and $\mathrm{D}_{2}$ dopamine receptors and thus may interact with dopamine agonists and antagonists[41].

Plants have formed the basis for the treatment of diseases in traditional medicine systems for thousands of years, and continue to play a major role in the primary health care of about $80 \%$ of the world's population. However, the prospect of current article is to review the changes in hormone level by medicinal plants. We have discussed numbers of medical plants and their importance that how they can alter the level of hormones such as Follicle stimulating hormone, Prolactin, Growth hormone, Insulin, Thyroxin, Estrogen, Progesterone, Testosterone, and Relaxin etc. The present review would thus be beneficial for the researcher working in the field of endocrinology.

\section{Conflict of interest statement}

The authors declare that they have no conflict of interest.

\section{References}

[1] Constanti A. Basic endocrinology for students of pharmacy and allied health sciences. Cleveland: CRC Press; 1998.

[2] Borrione P, Rizzo M, Quaranta F, Ciminelli E, Fagnani F, Parisi A, et al. Consumption and biochemical impact of commercially available plant-derived nutritional supplements. An observational pilot-study on recreational athletes. J Int Soc Sports Nutr 2012; 9(1): 28.

[3] Wagner KH, Reichhold S, Hölzl C, Knasmüller S, Nics L, Meisel M, et al. Well-trained, healthy triathletes experience no adverse health risks regarding oxidative stress and DNA damage by participating in an ultraendurance event. Toxicology 2010; 278(2): 211-216.

[4] Modi MB, Donga SB, Dei L. Clinical evaluation of ashokarishta ashwagandha churna and praval pishti in the management of menopausa syndrome. Ayu 2012; 33(4): 511-516.

[5] Gonzales GF, Cordova A, Vega K, Chung A, Villena A, Góñez C. Effect of Lepidium meyenii (Maca), a root with aphrodisiac and fertilityenhancing properties, on serum reproductive hormone levels in adult healthy men. J Endocrinol 2003; 176(1):163-168.

[6] Gonzales GF, Córdova A, Gonzales C, Chung A, Vega K, Villena A Lepidium meyenii (Maca) improved sperm parameters in adult men. Asian J Androl 2001; 3(4): 301-303

[7] Van Coppenolle F, Le Bourhis X, Carpentier F, Delaby G, Cousse H Raynaud JP, et al. Pharmacological effects of the lipidosterolic extract of Serenoa repens $\left(\right.$ Permixon $^{\circledR}$ ) on rat prostate hyperplasia induced by hyperprolactinemia: Comparison with finasteride. The Prostate 2000 43(1): 49-58

[8] Meier B, Berger D, Hoberg E, Sticher O, Schaffner W. Pharmacological activities of Vitex agnus-castus extracts in vitro. Phytomedicine 2000 7(5): 373-381.

[9] Wuttke W, Jarry H, Christoffel V, Spengler B, Seidlova-Wuttke D Chaste tree (Vitex agnus-castus)-pharmacology and clinical indications. Phytomedicine 2003; 10(4): 348-357.

[10]Brugisser R, Burkard W, Simmen U, Schaffner W. 10. Assessment of opioid receptor activity with Vitex agnus-castus. Z Phytother J 1999 20:154.

[11]Jarry H, Leonhardt S, Gorkow $\mathrm{CH}$, Wuttke W. In vitro prolactin but not $\mathrm{LH}$ and $\mathrm{FSH}$ release is inhibited by compounds in extracts of Agnus castus: Direct evidence for a dopaminergic principle by the dopamine 
receptor assay. Exp Clin Endocrinol 1994; 102(6): 448-454

[12]Mari A, Montoro P, D’Urso G, Macchia M, Pizza C, Piacente S.

Metabolic profiling of Vitex agnus castus leaves, fruits and sprouts: Analysis by LC/ESI/(QqQ) MS and (HR) LC/ESI/(Orbitrap)/MS n. J Pharm Biomed Anal 2015; 102: 215-221.

[13]Merz PG, Gorkow C, Schrödter A, Rietbrock S, Sieder C, Loew D, et al. The effects of a special Agnus castus extract (BP1095E1) on prolactin secretion in healthy male subjects. Exp Clin Endocrinol 1996; 104(6): $447-453$

[14]Ahmad B, Azam S, Bashir S, Khan I, Adhikari A, Choudhary MI. Antiinflammatory and enzyme inhibitory activities of a crude extract and a pterocarpan isolated from the aerial parts of Vitex agnus castus. Biotechnol J 2010; 5(11): 1207-1215.

[15]Kuruüzüm-Uz A, Ströch K, Demirezer LÖ, Zeeck A. Glucosides from Vitex agnus-castus. Phytochemistry 2003; 63(8): 959-964.

[16]Bleier W. Phytotherapy in irregular menstrual cycles or bleeding periods and other gynecological disorders of endocrine origin. Zentralblatt Gynakol 1959; 81(18): 701-709.

[17]Milewicz A, Gejdel E, Sworen H, Sienkiewicz K, Jedrzejak J, Teucher $\mathrm{T}$, et al. Vitex agnus castus extract in the treatment of luteal phase defects due to latent hyperprolactinemia. Results of a randomized placebocontrolled double-blind study. Arzneimittel-forschung 1993; 43(7): 752756.

[18]Lohning A, Verspohl EJ, Winterhoff H. Pharmacological studies on the dopaminergic activity of Cimicifuga racemosa. Abstract of the 23rd International LOF-Symposium on Phyto-Oestrogens. University of Ghent, Belgium; 1999.

[19]Koloszar S, Gellen J, Kovacs L. The value of plasma prolactin level determination in the diagnosis of postmenopausal osteoporosis. Orvosi Hetilap 1997; 138(2): 71-73.

[20]Borrelli F, Izzo AA, Ernst E. Pharmacological effects of Cimicifuga racemosa. Life Sci 2003; 73(10): 1215-1229.

[21]Jain S, Choudhary GP, Jain DK. Pharmacological evaluation of antifertility activity of ethanolic extract of Jatropha gossypifolia leaf in female albino mice. Asian Pac J Trop Biomed 2012; 2(3): S1671-S1674.

[22]Ganguly M, Devi N, Mahanta R, Borthakur MK. Effect of Mimosa pudica root extract on vaginal estrous and serum hormones for screening of antifertility activity in albino mice. Contraception 2007; 76(6): 482 485

[23]Ganguly M, Borthakur MK, Devi N, Mahanta R. Antifertility activity of the methanolic leaf extract of Cissampelos pareira in female albino mice. J Ethnopharmacol 2007; 111(3): 688-691.

[24]Sindhia VR, Bairwa R. Plant review: Butea monosperma. Int J Pharm Clin Res 2010; 2(2): 90-94.

[25]Maurya R, Yadav DK, Singh G, Bhargavan B, Murthy PN, Sahai M, et al. Osteogenic activity of constituents from Butea monosperma. Bioorganic Med Chemistry Lett 2009; 19(3): 610-613.

[26]Raj A, Singh A, Sharma A, Singh N, Kumar P, Bhatia V. Antifertility activity of medicinal plants on reproductive system of female rat. Int $J$ Bio-Engineering Sci Technol 2011; 2(3): 382-388.

[27]Bhargava SK. Estrogenic and postcoital anticonceptive activity in rats of butin isolated from Butea monosperma seed. J Ethnopharmacol 1986; 18(1): 95-101.

[28]Hiremath SP, Badami S, Hunasagatta SK, Patil SB. Antifertility and hormonal properties of flavones of Striga orobanchioides. Eur $J$ Pharmacol 2000; 391(1): 193-197.

[29]Razdan MK, Kapila K, Bhide NK. Study of the antioestrogenic activity of alcoholic extracts of petals and seeds of Butea frondosa. Indian $J$ Physiol Pharmacol 1970; 14(1): 57-60.

[30]Johri RK, Pahwa GS, Sharma SC, Zutshi U. Determination of estrogenic/ antiestrogenic potential of antifertility substances using rat uterine peroxidase assay. Contraception 1991; 44(5): 549-557.

[31]Gupta P, Chauhan NS, Pande M, Pathak A. Phytochemical and pharmacological review on Butea monosperma (Palash). Int J Agro Plant Prod 2012; 3(7): 255-258

[32]Keshri G, Singh MM, L akshmi V, Kamboj VP. Post-coital contraceptive efficacy of the seeds of Nigella sativa in rats. Indian J Physiol Pharm 1995; 39(1): 59-62.

[33]Agarwal C, Narula A, Vyas DK, Jacob D. Effect of seeds of kalaunji on fertility and sialic acid content of the reproductive organs of male rat. Geo Bios 1990; 17: 269-272.

[34]Boukhliq R, Martin GB, White CL, Blackberry MA, Murray PJ. Role of glucose, fatty acids and protein in regulating of testicular growth and secretion of gonadotrophin, prolactin, somatotrophin and insulin in the mature ram. Reprod Fertil Dev 1997; 9(5): 515-524.

[35]Hosseinzadeh H, Tafaghodi M, Mosavi MJ, Taghiabadi E. Effect of aqueous and ethanolic extracts of Nigella sativa seeds on milk production in rats. J Acupunct Meridian Stud 2013; 6(1):18-23.

[36]Lompo-Ouedraogo Z, van der Heide D, van der Beek EM, Swarts HJ, Mattheij JA, Sawadogo L. Effect of aqueous extract of Acacia nilotica ssp adansonii on milk production and prolactin release in the rat. $J$ Endocrinol 2004; 182(2): 257-266

[37]Osmers R, Friede M, Liske E, Schnitker J, Freudenstein J, Henneickevon Zepelin HH. Efficacy and safety of isopropanolic black cohosh extract for climacteric symptoms. Obstet Gynecol 2005; 105(5, Part 1): 1074-1083.

[38]Amato P, Christophe S, Mellon PL. Estrogenic activity of herbs commonly used as remedies for menopausal symptoms. Menopause 2002 9(2): $145-150$.

[39]Liu J, Burdette JE, Xu H, Gu C, Van Breemen RB, Bhat KP, et al. Evaluation of estrogenic activity of plant extracts for the potential treatment of menopausal symptoms. J Agric Food Chem 2001; 49(5): 2472-2479.

[40]Du MC. Vitex Agnus castus. Aust J Med Herbalism 1993; 5: 63-65.

[41]Jarry H, Leonhardt S, Wuttke W, Behr D, Gorkow CH. Agnus castus als dopaminerges Wirkprinzip in Mastodynon. Z Phytather 1991; 12: 77. 